\title{
THE EMBEDDING OF ISLAMIC EDUCATION VALUES IN THE DEVELOPMENT OF STUDENT CHARACTERS AT AL-IKHLAS ISLAMIC HIGH SCHOOL IN UJUNG-BONE
}

\author{
Hasbi Siddik \\ State Islamic Collage (STAIN) Sorong \\ Jl. Basuki Rahmat No. 40, Kota Sorong, Papua Barat, Indonesia \\ E-mail: jalanbima762@gmail.com
}

\begin{abstract}
The Embedding of Islamic Education Values in the Development of Student Characters at al-Ikhlas Islamic High School in Ujung-Bone. This article starts from three main problems: embedding character values at Al-Ikhlas Madrasah Aliyah of Ujung-Bone, encountering the opportunities and challenges during the process. This qualitative research is based on phenomena that occur in the field. The approaches used are pedagogical analysis, normative and juridical approach. The results explain, that the character security processes carried out by teachers are to be honest, responsible, nationalism, social care, affection, tolerance, discipline, and creative in developing their potential. They attempt to guard the educational process of cultivating character by conducting behavioral supervision of students. Embedding students' character can motivate and tell the story of successful people. The strong desire of stakeholders to foster and advance Madrasah is in accordance with the expectations of the founders. Although, there are limited standard specifications of educational staffs, the values of Islamic education are very important in the joints of life. Therefore, Islamic education inherits human values to students, encourages students, not only to equip themselves for individual interests, but also to devote themselves to the community.
\end{abstract}

Keywords: character education; normative values; supervision; commitment to progress.

\begin{abstract}
Abstraks: Penanaman Nilai-Nilai Pendidikan Islam dalam Pengembangan Karakter Siswa di Madrasah Aliyah alIkhlas, Ujung-Bone. Artikel ini, berawal dari tiga masalah pokok, yakni bagaimana proses penanaman nilai-nilai karakter di Madrasah Aliyah Al-Ikhlas Ujung, Kabupaten Bone, penanaman nilia-nilai pada peserta didik, serta peluang dan tantangan yang dihadapi dalam proses edukasi. Penelitian ini bersifat kualitatif yang bertumpu pada fenomena yang terjadi di lapangan. Pendekatan yang dipakai sebagai analisisnya adalah pendekatan pedagogik, normatif dan yuridis. Hasil penelitian ini menjelaskan bahwa proses penamanan karakter yang dilakukan oleh para guru di Madrasah Aliyah Al-Ikhlas adalah harus bersifat jujur, bertanggung jawab, cinta tanah air, peduli sosial, cinta damai, toleransi, disiplin, dan kreatif sebagai nilai positif dalam mengembangkan potensi diri. Upaya para guru dalam mengawal proses tersebut dilakukan dengan pengawasan terpadu terhadap perilaku peserta didik, pemberian motivasi, serta memberikan kisah-kisah orang sukses. Keinginan yang kuat dari stakeholders untuk membina dan memajukan Madrasah tersebut telah sesuai dengan tuntutan haparan pendirinya. Walaupun terbatasnya tenaga kependidikan yang mempunyai spesifikasi standar khusus di bidangnya. Nilai-nilai pendidikan Islam sangatlah penting dalam sendi-sendi kehidupan. Oleh sebab itu, pendidikan Islam mewariskan nilai-nilai kemanusiaan kepada peserta didik. Mendorong peserta didik tidak sekadar membekali dirinya untuk kepentingan individu, melainkan mendarmabaktikan dirinya kepada masyarakat.
\end{abstract}

Kata kunci: pendidikan karakter; nilai normatif; pengawasan; komitmen kemajuan.

\section{Introduction}

Islamic boarding schools as religious education institutions are the oldest institutions in Indonesia that have their own peculiarities. ${ }^{1}$

Siti Mahmudah Noorhayati, "Pendidikan Multikultural Di Pesantren, (Upaya Membendung Radikalisme di Indonesia)", Jurnal Madania, Vol. 21, No.1, June, 2017, p.
They have been playing a big role in educational field of the nation. Islamic boarding schools are rich in normative values about Islamic values and educations. The concept of Islamic education is normatively loaded with transcendental values of the Divine and Human. ${ }^{2}$ All of them are under a

Said Aqil Siraj, Tarbiyah dan Kebangsaan: Kontribusi Kaum 
theory called humanism-theocentric. Educational theory will not have a significant social impact without action. The character values of humanismtheocentric as the ideological paradigm of Islamic education are used to emphasize the need for action. ${ }^{3}$ The nature of education is the process of improving human self, continuing from one generation to another. 4

Character distinguishes human from other living things. Because of the importance of character values, educational institutions have the responsibility to conduct coaching through the learning process. ${ }^{5}$ This assessment is based on the number of school graduates and scholars who are intellectually intelligent, but who are mentally weak and behave inappropriately with the purpose of education. ${ }^{6}$ One of the factors is the inability to balance the needs of the community with the purpose of education, as well as the demand for the development of increasingly rapid science and technology. ${ }^{7}$

Character building has a personal integrity that are strong, wise and open. Character can avoid mental attitude of nihilism, hedonism, and intellectual alienation. ${ }^{8}$ Intellectuals with such qualifications are the ones that are able to describe Islamic values in a systematic, integrated and holistic way, and relevant to the challenges of the modern world. ${ }^{9}$ There are 9 of character buildings that are come from universal noble values: (1) the character of God's love to all of His creations; (2) independence and responsibility;

Santri Melampaui Eksklusivisme in "Tasawuf Sebagai Kritik Sosial, Mengedepankan Islam sebagai Inspirasi, Bukan Aspirasi, (Bandung: Mizan, 2006), p. 236.

${ }^{3}$ Achmadi, Ideologi Pendidikan Islam, (Yogyakarta: Pustaka Pelajar, 2010), p. vii.

${ }_{4}$ Doni Koesoema A, Pendidikan Karakter: Strategi Mendidik Anak di Zaman Global (Jakarta: Grasindo, 2007), p. 312.

${ }_{5}^{5}$ Zubaedi, Desain Pendidikan karakter Konsepsi dan Aplikasinya dalam Lembaga Pendidikan (Jakarta: Kencana, 2011), p. 1.

${ }^{6}$ Zubaedi, Desain Pendidikan Karakter ..., p. 1. See. Akhmad Muhaimin Azzet, Urgensi Pendidikan Karakter di Indonesia: Revitalisasi Pendidikan Karakter terhadap Keberhasilan Belajar dan Kemajuan Bangsa (Jakarta: Ar-Ruzz Media, 2011), p. 9.

7 Muhaimin Abdul Majid, Pemikiran Pendidikan, Kajian Filosofis dan Kerangka Dasar Operasionalisasinya , (Bandung: Trigenda Karya, 2007), p. 71.

8 Azyumardi Azra, Esei-esei Intelektual Muslim dan Pendidikan Islam, (Jakarta: Logos Wacana IImu, 1998), p. 27.

9 Noeng Muhadjir, Ilmu Pendidikan dan Perubahan Sosial: Suatu Teori Pendidikan, (Yogyakarta: Rake Sarasin, 2007), pp. 20-25.
(3) diplomatic honesty; (4) respect others and be polite; (5) be generous and helping others; (6) confident and hard worker; (7) having a good leadership and righteous; (8) kind hearted and humble; (9) having character of tolerance, peace, and unity. These pillars of character are taught systematically in a holistic education model using the method of knowing the good, feeling the good, and acting the good.

Madrasah Aliyah al-Ikhlas of Ujung is part of al-Ikhlas Islamic Boarding School of Ujung in Bone, South Sulawesi. This boarding school was established as a manifestation of the concern of its founders on the reality in society. This Madrasah Aliyah is based on a boarding school system that is bulit to shape the character of the students. This system is considered to be more effective in preventing adolescents from committing juvenile delinquency in the form of promiscuity, drug abuse and addictive substances which recently has increased in numbers. ${ }^{10} \mathrm{Al}-$ Ikhlas Boarding School has special program which integrates common sciences and religious sentences. In addition to implementing the curriculum according to National standards, the school conducts special programs for its students. The purpose of the special program is to improve the character of the students so they are able to face the challenges in this rapidly changed era since Islamic system of values and character can be used as a foundation of life.

In the new curriculum of 2017/2018, al-lkhlas Boarding School of Ujung opens an acceleration class that makes academic years of Madrasah Aliyah and Madrasah Tsanawiyah a year shorter. This class has a purpose to accelerate the achievement and maturation of the students. From the discussion above, these are the main issues of this article: how does the process of implementing of Islamic values in education in Madrasah Aliyah of Ujung in Kab. Bone? What efforts that have been made by the teachers in developing educational values?

This research has become necessary, given the progress and relevance of Madrasah Aliyah are important in community in implementing

\footnotetext{
${ }^{10}$ Profile of Madrasah Aliyah Al-Ikhlas Ujung -Bone, 2018
} 
character to the students, since character building has personal integrity that are strong, wise and open. In the tradition of Islamic boarding school, the characteristics that should be implemented by the students are attitude of modesty, diligence, istiqomah and sincerity. The tradition is far from characteristics of nihilism, hedonism, and intellectual alienation. ${ }^{11}$ Intelectual students with these characteristics are the ones that are able to describe Islamic values in a systematic, integrated and holistic way, and relevant to the challenges of the modern world. ${ }^{12}$ There are 9 character buildings that come from universal noble values: (1) the character of God's love to all of His creations; (2) independence and responsibility; (3) diplomatic honesty; (4) respect others and be polite; (5) be generous and helping others; (6) confident and hard worker; (7) having a good leadership and righteous; (8) kind hearted and humble; (9) having character of tolerance, peace, and unity. These pillars of character are taught systematically in a holistic education model using the method of knowing the good, feeling the good, and acting the good.

The significance of this study was to find out the process of implementing Islamic values in Madrasah Aliyah of Ujung in Kab. Bone and to review the educational methods used by teachers in developing character values and formulating opportunities and challenges in character building. In addition, the advantages expected of this study are (1) as a contribution of ideas for the development of science, especially for character building of the students; (2) as motivation to Islamic education experts to more thoroughly assess the values of education; (3) to increase the number of literatures of Islamic education and and become a reference for educators in implementing Islamic values.

\section{Theoritical Framework}

There are three environments that shape the characteristics of human beings; family,

\footnotetext{
11 Azyumandi Azra, Esei-esei Intelektual Muslim dan Pendidikan Islam, (Jakarta: Logos Wacana Ilmu, 1998), p. 27.

12 See Noeng Muhadjir, Ilmu Pendidikan dan Perubahan Sosial: Suatu Teori Pendidikan, (Yogyakarta: Rake Sarasin, 2007), pp. 20-25.
}

school and society. Three of them are commonly reffered as three centers of education. ${ }^{13}$ The implementation of Islamic values in education has three objectives. First, to prepare the younger generation to play a certain role in society in the future. Second, to transfer knowledge in accordance with the role expected. Third, to transfer values in character building to maintain the integrity and unity of society. ${ }^{14}$ The second and third objective has a point that education is not only a matter of transferring the knowledge, but also transferring the value. ${ }^{15}$ The character of humanity as the caliph of Allah on earth which confirms individual and social, as well as moral abilities. ${ }^{16}$ The objectives to be achieved are clearly and accurately formulated to optimize the three objectives based on the values and culture of Islamic teachings. ${ }^{17}$

Islamic education is truly oriented to make people achieve universal balance in building human character and morality. This can be done through certain stages with the intensity of the training towards psychological aspects, reason, thoughts, feelings, the five senses and moral values. ${ }^{18}$ Islamic education institutions cannot eliminate the orientation of moral building. Character building is full education that shapes mind and heart, spiritual and physical, morals and skills of human being. ${ }^{19}$ The process of Islamic education aims to achieve individual, social and professional objectives. ${ }^{20}$ The three objectives are integrated and directed to be achieved in the process of moral education, which is to build individuals who are devoted and serve God.

\footnotetext{
${ }^{13}$ See Profile Madrasah Aliyah Al-Ikhlas..., p. 312.

14 Hasan Langgulung, Beberapa Pemikiran tentang Pendidikan Islam, (Bandung: al-Ma'arif, 1980), p. 92.

${ }^{15}$ Muslih Usa (ed), Pendidikan Islam di Indonesia antara Cita dan Fakta, (Yogyakarta: PT Tiara Wacana Yogya, 2001), p. 27.

${ }^{16} \mathrm{M}$. Arifin, Ilmu Pendidikan Islam Suatu Tinjauan Teoritis dan Praktis Berdasarkan Pendekatan Interdisipliner, (Jakarta: Bumi Aksara, 1991), p. 33.

${ }^{17}$ Azyumardi Azra, Pendidikan Islam Tradisi dan Modernisasi Menuju Milenium Baru (Jakarta: Logos Wacana IImu), 2007, p. vii.

${ }^{18}$ Ahmad D. Marimba, Pengantar Filsafat Pendidikan Islam, (Bandung: al-Ma'arif, 2000), p. 23.

19 Yusuf al-Qardhawi, Pendidikan Islam Dan Madrasah, Hasan al-Banna, Trans. Bustami A.Gani and Zainal Abidin Ahmad, (Jakarta: Bulan Bintang, 1980), p. 39.

20 Omar Muhammad al-Toumy al-Syaibani, Falsafah Pendidikan Islam, Trans. Hasan Langgulung, (Jakarta: Bulan Bintang, 2003), p. 399.
} 
The study of the transformation of Islamic education values in character building in the future needs to be emphasized in the aspects of cognitive, affective and psychomotor intelligence of students. These aspects cannot be separated from elements, such as institutions, teachers, students, curriculum, content standards, process standards, environment, and learning models used by the teachers. These will determine the expected learning outcomes both in the form of teaching impact and leading impact.

The learning model is a teaching plan that pays attention to certain learning patterns. Learning models develop in accordance with the development of the needs of students. Professional teachers are required to be able to develop learning models, both theoretical and practical, which cover aspects, concepts, principles, and techniques. Choosing the right model is a requirement to help students in achieving teaching goals. The model of institutional development directly influences the success of the learning process. In using learning model as a teaching strategy in learning, the teachers should pay attention to the five key aspects of effective learning: (1) clarity, (2) variety, (3) task orientation, (4) involvement of students in learning, and (5) achievement of success. ${ }^{21}$

Objective conditions can be seen in various results of research data. Muhaimin stated that the process of managing learning in institutions, especially in Madrasah, has not been implemented optimally, so its role as an educational institution oriented to the value building of faith and devotion to Allah and noble character cannot be achieved effectively. Some factors causing low role and effectiveness of Islamic education for students to believe and devoted to Allah Swt and have noble character are:

1. The education has been carried out using a learning approach that is not in accordance with the objectives to be achieved.

2. Learning material that is more theoretical, fragmented, or less related to other subjects and even between sub-subjects, such as

${ }^{21}$ Dharma Kesuma other, Pendidikan Karakter: Kajian Teori dan Praktik di Sekolah..., p. 12.
Quran, Faith, Morals, Fiqh and Islamic History (târikh) which are taught separately.

3. The learning model is conventional, which more emphasises on enrichment of knowledge (cognitive at a low level) than the building of attitudes (affective) and habituation (psychomotor). Thus, Islamic education aims to teach students to have knowledge about the values of Islam and be able to apply it in the form of noble morals. ${ }^{22}$

Efforts to review the implementation of learning in formal education institutions, especially in Madrasah, are increasingly urgent when associated with reality in the field, such as;

a. Some beliefs based conflicts that has happened in several regions.

b. Moral crisis with the increasing number every year of crimes, such as brawls, drug abuse and others.

\section{Method}

This study used qualitative research method aimed to describe phenomena existed in the community. The phenomena can be in the form, activities, characteristics, changes, relationships, similarities. ${ }^{23}$ Qualitative research is a holistic research, where planning, carrying out data collection, analysis, interpretation of data, and reporting the results of research are conducted by researchers. ${ }^{24}$

The analysis used in this study was descriptive qualitative, namely non-statistical analytic with an inductive approach in which the analysis of the data departs from the problem and the specific theme used as the focus of the research. ${ }^{25}$ The author conducted three ways to process this research data. The first was reduction, i.e. choosing, simplifying, focusing, abstracting and changing rough data from notes. ${ }^{26}$ The second was display, which is a way of assembling data

\footnotetext{
${ }^{22}$ Zubaedi, Desain Pendidikan Karakter ..., p. 247.

${ }^{23}$ Sukmadinata, Metode Penelitian Pendidikan, (Bandung: Rosdakarya, 2006),p. 72.

${ }_{24}$ Sugiyono, Metode Penelitian Pendidikan Pendekatan Kualitatif, Kualitatif, dan R\&D (Bandung: Alfabeta, 2008), p. 5.

${ }^{25}$ Sugiyono, Metode Penelitian Pendidikan..., p. 11.

${ }^{26}$ Muhammad Ali, Strategi Penelitian Pendidikan, (Bandung: Angkasa, 2007), p. 167.
} 
in an organization that makes it easy to make conclusions or proposed actions. ${ }^{27}$

\section{Objectives Condition of Madrasah Aliyah al-Ikhlas Students}

Islamic Education course is strongly demanded to create maximum results, especially in preparing students to have religious and humanistic behavior. Religious approach applied in all formal educational institutions is theological and "Scientific Cum Doctrinaire" as stated in Mukti Ali's theory in 1980s. By using this approach, the truth claim of the students' religiosity is expected to be more developed. Their theological critical power is also expected to be developed in the frame of exclusive conventional religious pluralism. The role of religion teachers needs to get more attention so the harmony of diversity for all religious adherents can be formed. A religion teacher is a person who has broad religious knowledge as well as a good believer of his religion. ${ }^{28}$ Therefore, the religion teachers, especially the Islamic Studies teachers, are expected to become religionists and role models for students in schools and society so the Muslims as "rahmatan lil "âlamîn" can be realized. ${ }^{29}$

Generally, interaction between teachers and students showed good attitudes, except when the students did not do the assignments given by the teachers well. When riding motorcycle, some of the students violated the traffic rules such as three people riding one motorcycle without wearing helmet. In addition, some of the students behaved negatively and deviated from both religious and moral values such as arriving late, ditching school, not participating in congregational prayer at the mosque, skipping ceremony on Monday and lacking of discipline in dressing.

Muhammad Ahdar, a teacher, also stated that the students' behavior was still reasonable

${ }^{27}$ Muhammad Ali, Strategi Penelitian Pendidikan..., p. 168.

${ }^{28}$ M. Atho Mudzhar dkk, Damai di Dunia Damai Untuk Semua: Perspektif Berbagai Agama, (Jakarta: Badan Litbang dan Diklat Keagamaan Departeman Agama RI, 2004), p. 1437

29 M. Saerozi, Politik Pendidikan Agama dalam Era Pluralisme, (Yogyakarta: Tiara Wacana Yoga, 2004), p. 157 and did not make big problems for the teachers. However, their actions were considered violating the rules of the school, for example coming late to school, ditching school, and not participating in congregational prayer at the mosque. The students who did those violations would only be warned and lectured by the teachers. ${ }^{30}$ There were many students in Madrasah Aliyah alIkhlas who behave poorly, especially in terms of attendance, dressing, and social ethics. Therefore, the interaction and communication between counseling teachers and the parents are needed. This study puts the parents as the source of information, especially in the learning behavior and religious life of the students when they are at home with their family. Parents are the first and main educators who deal directly with their children. The students' behavior at home influences their attitudes at school. Therefore, the writer did an interview with some of the students' parents that were considered as the representatives. ${ }^{31}$

Regarding the academic achievement and learning behavior of their children, the parents said that the learning behavior of their children were quite good, their academic achievements were good too. Their children tend to enjoy studying. They also always gave their children motivation, attention and telling them about the importance to compete in terms of academic achievements. Regarding connecting cards, they agreed because the management of the students' behavior was a shared responsibility of the school and the parents. ${ }^{32}$ One of the students' parents in Madrasah Aliyah al-Ikhlas stated that parents always paid attention to their children behavior, both at home and toward their friends, and ensuring that everything is normal and positive. However, they did not know about the children behavior at school because it was the teachers' responsibility to supervise them. This was the reason why they needed a controlling instrument

30 Interview with Muhammad Ahdar, Matriculation Teacher of Madrasah Aliyah Al-lkhlas, February 9, 2018.

31 Interview with Muhammad Ahdar, Matriculation Teacher of Madrasah Aliyah Al-Ikhlas, February 10, 2018.

32 Interview with Muhammad Nasri, student parent Aldi Hidayat, $12^{\text {nd }}$ class of Madrasah Aliyah Al-lkhlas, February 9, 2018. 
from school for the parents so both parties could get information about the children behaviour. ${ }^{33}$

Improving the quality of resources was carried out in harmony with the prophetic mission objectives, first, increasing the school's performance in both academic and non-academic achievement through innovation in learning input and process, second, improving teachers' competency and reward system, third, improving the quality of learning process, developing teaching materials and providing effective guidance so the students can develop optimally in accordance with their own potentials, fourth, creating both teaching and leaning environment that used English, fifth, fostering appreciation of the religious teachings and national culture so they became sources of wisdom in their action, sixth, developing achievement standards for competencies and improving their achievement in both intra and extra-curricular, seventh, improving the equality in education, eighth, applying participation mechanism that involving the residents and committees in school, ninth, developing assessment standards. ${ }^{34}$

\section{The Stages of Learning}

The initial activities after entering the classroom can be organized into several activities, which in this study are (1) formal greeting, (2) explaining the specific learning objectives, (3) the technique that attracts the students' attention, and (4) linking the old subjects with the new ones. Formal greeting is one of the communication principles in Islamic society. The communication applies in all kind of social activities. In carrying out various activities in the school, the religion teachers are obliged to accustom to greeting. ${ }^{35}$ According to the informant, it was difficult to accommodate the students that have different interests in arousing their attention to keep up with learning process in class.

Activities in the core of learning. The core

${ }^{33}$ Interview with Nandar Trijaya, Student parent, February 9, 2018.

34 Interview with Muhammad Ahdar, Matriculation Teacher of Madrasah Aliyah Al-Ikhlas, February 10, 2018.

35 Interview with Abdul Gani, Islamic Historical Culture Teacher of Madrasah Aliyah Al-Ikhlas, February 15, 2018. activities of learning are limited to the activities such as; giving keywords, explaining teaching materials with examples, focusing attention, giving simple guidance to understand the materials, giving exercises that are related to the materials and providing feedbacks on the students' performance. The results of the study showed that the core presentation in writing included learning activities, the explanation of the teaching materials and its technique. The observation done by the researcher and the students' assessment on the core presentation was limited to indicators.

Keywords are concepts, rules, and core procedures of a subject discussed at each meeting. The concept of keywords can be in the form of terms definition as well as information on prerequisites to clarify or retract memories of concepts previously possessed by students, in the design of textbooks or dictates that is not specifically found in those key words. The information process basically has broad implications for various aspects of teaching. The information process can be seen in terms of the application of teaching methods, the application patterns of interaction, and the procedural stages of teaching from beginning to end. Moreover, it can also be seen from the mindset approach of this context. The researcher observed the implementation of the information process from the use of teaching methods and communication patterns or the interaction of the teachers and the students, and the delivery of informant's mindset. ${ }^{36}$

Regarding the students' attention, basically its implementation is not different from the drawing attention technique in the preliminary phase of learning. Focusing attention on the core presentation refers to the part of material that is temporarily presented. The observation result showed that the informants had various techniques that were different from one another. The students confessed in the interview that they generally thought that every informant did it. ${ }^{37}$ Practical instruction in learning the teaching

${ }^{36}$ Interview with Abdul Gani, Islamic Historical Culture Teacher of Islamic Historical Culture, February 16, 2018

37 Interview with Abdul Gani, Islamic Historical Culture 
materials. Activities regarding written technical instructions are not found in various written documents. However, the informants, named $\mathrm{KI}$ and $\mathrm{KD}$, once gave technical instructions on how to deal with a dead body in Islam. ${ }^{38}$

All of the informants used guidebooks from the school. The teachers gave the students assignment to work on worksheets for each subject. The work of students was generally examined outside the teaching hours, there were even informants who brought them to their homes. ${ }^{39}$ It certainly had positive impact on the acceleration of learning process. The feedbacks given by the informants were limited to the reinforcement, for example, when the students were able to answer the question correctly, the teachers would praise them. On the other hand, when the students gave wrong answers, the teachers would say, "The answer is not wrong, but it needs more explanation", in relation to the results of the worksheet. Generally, the informants always gave feedbacks on the students' performance.

Closing activities were including giving assignments, conducting final exam and creating resume. The results of observation showed that the closing activities that were listed in the lesson plan (RPP) were not always in accordance with the things that the informants did in the closing activities. One of the reasons was explained in the results of the following interview:

We could not do everything that listed in the lesson plan, especially the ones related to the closing activities such as giving conclusion and conducting final exam. It was caused by the limited of time, especially when we used the discussion method.

Other than the three closing activities, some of the activities that related to the closing activities were conducting formative exam, providing feedbacks on the performance, also giving both follow-up and re-motivation.

\footnotetext{
Teacher of Madrasah Aliyah Al-Ikhlas, February 16, 2018

${ }^{38}$ Interview with Abdul Gani, Islamic Historical Culture Teacher of Madrasah Aliyah Al-Ikhlas, February 16, 2018

39 Interview with Abdul Gani, Islamic Historical Culture Teacher of Madrasah Aliyah Al-Ikhlas, February 17, 2018
}

\section{The Effort of the Teachers in Character Building}

The concept of character education was a system aimed to develop good moral values in the students including knowledge, willingness and actions to do those values. Regarding the implementation of character building in the school, all of the school's components had to be involved, including the education components such as curriculum, learning and assessment process, the subjects management, the school management, the activities' implementation or extra-curricular activities, the empowerment of the facilities and infrastructures, financing and work ethics of the people in the school and the ones in the students' environment. ${ }^{40}$ The results of the interview and observation showed that the teachers did strategic steps in the process of character building as follows:

a. Integrated Supervision. An integrated supervision was conducted by all of the components in the Madrasah Aliyah AlIkhlas towards the students' behavior. Both students and teachers' discipline in learning, praying, and time to attend the school and come home were monitored. However, there were also the students who committed minor offences but it could not be categorized as not having good characters. In order to anticipate the crisis of characters, the head master asked all of the teachers to apply active learning strategies in learning process. In addition, creating the teachers' synergy in building the good characters in the students by integrating moral values in each subject was needed. ${ }^{41}$ Integrated supervision from all of the school's element in building good characters for the students was a positive effort in creating reliable human resources.

b. Giving motivation. In order to internalize character values in the students, the teachers had to give motivation through advises and the stories of successful people. Moreover, the Islamic Education teacher (Al-Quran,

${ }^{40}$ Interview with Abd. Rajab, Head Master of Madrasah Aliyah Al-Ikhlas, February 1, 2018.

${ }^{41}$ Interview with Abd. Rajab, Head Master of Madrasah Aliyah Al-Ikhlas, February 1, 2018. 
Hadist, Fiqih, Akidah Akhlak and Arabic Language) did not only focus on building methodological ability in religious knowledge, but also creating synergy with the general subjects teachers so they could also monitor the students' behavior. It became the responsibility of every teacher. ${ }^{42}$ Therefore, positive motivation was one of the ways in building character.

c. Applying Active Learning Strategies. Applying appropriate active learning strategies, reviewing the learning methodologies, building cooperation between the teachers and the students' parents. The connecting cards needed to be re-activate outside of the school hours. ${ }^{43}$

d. Extra-Curricular Activities. The observation on the condition of the students' behavior showed that the model of active learning strategy applied by the school in order to internalize character values in the students was carrying out learning process outside of the school hours through extra-curricular activities. ${ }^{44}$

e. Study Group. The interview result showed that Islamic Education learning process refered to process approach, while the strategy to develop internalization of character values on students was by forming study groups supervised by competent teachers. So the supervised teachers were not always Islamic teacher. In this case, the good teamwork among teachers was needed. ${ }^{45}$

\section{Embedding Main Character Building}

From the observation and interview with the headmaster and several permanent teachers in the Madrasah, there were several main characters that became the goal of this secondary education institution, among of them are:

${ }^{42}$ Interview with Abd. Rajab, Head Master of Madrasah Aliyah Al-lkhlas, February 1, 2018.

${ }^{43}$ Interview with Muhammad Safri Abdullah, Arabic Teacher of Madrasah Aliyah Al-Ikhlas, February 2, 2018.

${ }^{44}$ Interview with Muhammad Irham, Fiqh Teacher Madrasah Aliyah Al-Ikhlas, February 4, 2018.

45 Interview with Muhammad Irham, Fiqh Teacher Madrasah Aliyah Al-Ikhlas, February 4, 2018. a. Honesty. Honesty is a behavior that makes a person can always be trusted in his/her words, actions, and efforts either to his/herself or other people. The development of honesty values on the students of Madrasah Aliyah al Ikhlas of Ujung, Kab. Bone, contained comprehensive and integrated teachings, managing every aspect of human life in world as well as in hereafter. While education is the matter that cannot be separated from Islamic teaching, it is an integrated part of islamic teaching aspect. Honesty is a part of Islamic teaching and also character teaching. Honesty is a good behavior. Allah appreciates people who speak honest and promises rewards for them. ${ }^{46}$

b. Responsibility. The process of building responsibility trait among students is considered as a trait and behabior of a person to do their task and responsibility that should have been conducted for themselves, society, environment (nature, social, \& culture), country and Allah Swt. Responsibility is a good trait that is fundamental in human. This trait is in line with fitrah but also can be shifted by external factors. Every individual has this trait. It will be better if the personality of that person becomes better. It will always be in human nature because fundamentally, every human cannot get away from responsibility and demand of life. 47 It causes a different frequency of responsibility in every person. Responsibility is closely related to feeling, such as feeling of conscience that has great impact to make our behavior become positive.

c. Patriotism. Patriotism is a feeling that emerges from the heart of citizen to serve, preserve, fight, and protect his/her country from any threats..$^{48}$ Patriotism is a feeling of pride, a sense of belonging, respect, appreciation and loyalty that belongs to every person for their countries. This behavior reflects from the act to fight and protect, willing to

${ }^{46}$ Interview with Abd. Rajab, Head Master of Madrasah Aliyah Al-Ikhlas, February 6, 2018.

47 Interview with Abd. Rajab, Head Master of Madrasah Aliyah Al-Ikhlas, February 6, 2018.

48 Interview with Muhammad Safri Abdullah, Arabic Teacher of Madrasah Aliyah Al-Ikhlas, February 2, 2018. 
sacrifice for their countries, love the culture and custom by preserving it.

d. Social Care. Compassion is a feeling that emerges within oneself to love and give a joy to other people or whoever they love. One of principals and values of brotherhood among human is "compassion" (al-mua'akhah bi almawaddah) that must be instilled by human. In principal, compassion is a part of 'moral integrity' that becomes a guidance of human honor. In religious societies, appreciation of religious teachings will positively lead to behavior positively, including the attitude of human affection. ${ }^{49}$ In short, life will be wonderful if we always love each other regardless of differences. The meaning of compassion is always doing the best to have a relationship between us with God, human, nature and other living things in this world. In conclusion, the value of love is the gift of God that is desirable to be instilled all the time. It is part of an important element in building a loving and moral society. ${ }^{50}$

e. Tolerance. Tolerance is a human trait that does not chatter rules, where a person respect other people action. Tolerance is a term in the contex of social, culture, and religion that means traits and behavior that forbid discrimination on particular groups or cannot be accepted by majority in society. ${ }^{51}$ In an interview with $\mathrm{H}$. Abd. Rajab, the way to preserve tolerance are: create comfort, reject intolerance on children, support children when they become the victim of intolerance, assist development of healthy experience and group identity, show display that contains cultural differences in home, give chances for children to interact with different people, push children to visit sources in nearby environment, be honest with the differences and give example to other people. ${ }^{52}$ In conclusion, tolerance is

49 Interview with Muhammad Safri Abdullah, Arabic Teacher of Madrasah Aliyah Al-Ikhlas, February 2, 2018.

${ }^{50}$ Interview with Herman, English Teacher of Madrasah Aliyah Al-Ikhlas, February 13, 2018.

51 Interview with Herman, English Teacher of Madrasah Aliyah Al-Ikhlas, February 13, 2018.

52 Interview with Herman, English Teacher of Madrasah strongly needed to be taught in students, because tolerance is one of harmonious social orders.

f. Discipline. Discipline is to familiarize oneself to do everything in a continuos manner to achieve goal and purpose in life. It is a habitual cycle that is conducted repeatedly and continuously. Discipline is an action that is conducted consistenly and continously that can be habit to achieve a goal.

g. Creative. Creativity is a mental process that involves the emergence of new ideas or concepts (concepts), or new relationships between ideas and existing ones. ${ }^{53}$ From a scientific perspective, the result of creative thinking (sometimes called branch thinking) is usually considered to have authenticity and appropriateness. As an alternative, the daily conception of creativity is the act of making something new. There are so many creative definitions presented by the characters before us, and we often say the word "creative" indirectly, for example when we see our friends are able to design their clothes with models other people never used, we indirectly say things like this "how come you really are creative”. Isn't it creative that something is an idea in which there is an innovative element, which is innovative is the ability of an individual to create new things.

h. Independence. Independence means being able to live life with one's own abilities, the ability to do something alone without much involving the help of others. Every one of us who wants to succeed needs an independent attitude, because independence is an attitude that is absolutely necessary as the main prerequisite for achieving various successes in this life. As a positive attitude, we all need to be independent. ${ }^{54}$ It does not only have to depend on the help of others who usually have a compromise in it (there is a

\footnotetext{
Aliyah Al-Ikhlas, February 13, 2018.

53 Interview with Herman, English Teacher of Madrasah Aliyah Al-Ikhlas, February 13, 2018.

54 Interview with Herman, English Teacher of Madrasah Aliyah Al-Ikhlas, February 14, 2018.
} 
bargain) which makes us precisely sometimes become our own difficulties with the help of these other parties. As social beings, people are required to live to help each other, and cannot live alone without the help of others, but this is not a reason for humans not to live independently. Therefore, independence is a form of optimal self-empowerment to be able to produce works that are useful for future lives of course.

i. Democracy. In the interview with Abd Rajab, democracy would be properly conducted if supported by democratic citizens' behavior. Likewise, democracy in a country will only grow if preserved by democratic citizens. The citizens can not only enjoy individual freedom, but also be able to assume responsibility together with others to shape a bright future. Citizens need to show democratic behavior..$^{55}$ It is a behavior that can support the establishment of democratic principles. The democratic behavior of citizens is a reflection of the existence of a democratic personality, the formation of character for the national community, including students..$^{56}$

\section{Opportunities and Challenges for Character Building at Madrasah Aliyah al-Ikhlas Ujung- Bone}

There are some interesting findings in this study. The dynamics of developing positive character values to students is not as easy as pouring water into a glass and then absorbing it well. A variety of methods, strategies, praxis tricks, and patience as well as firmness in developing these values are needed.

In life at Madrasah Aliyah al-Ikhlas, students seemed good and polite; they said good words and performed good deeds. Rudi Hartono explained that basically, the teachers had tried their best to apply the appropriate material and methods in the learning process, an explanation of the character values contained in the material. It is expected that students can master the lesson

${ }^{55}$ Interview with Abd. Rajab, Head Master of Madrasah Aliyah Al-Ikhlas, February 14, 2018.

${ }^{56}$ Interview with Abd. Rajab, Head Master of Madrasah Aliyah Al-Ikhlas February 14, 2018. and implement it in their daily lives.

The behavior of students in Madrasah Aliyah al-Ikhlas towards teachers and their fellow people in general was very good, polite, and respectful. They were discipline during the time when class started and ended. Nevertheless, it is undeniable that there were students who did not focus on learning, and even disturbed the learning process, especially during the last lesson ${ }^{57}$ The behavior of basic students was still reasonable, not disturbing the teacher. They sometime violated the Madrasah rules, for example being late in entering class, skipping school, not participating in congregational prayer at the mosque. It is still common to find some students behaving poorly, so they need attention, especially in terms of attendance, dress, social ethics. Therefore, consulting teacher needs to make interaction and communication with parents of students ${ }^{58}$ Idris Rasyid added that the teachers often served parents of students to provide an understanding of their children's behavior, especially in terms of truant, not joining the class for several days without news, fighting with classmates. Meeting with their parents is the best way to make improvements to the negative behavior of students in the Madrasah. 59

From studies that have been carried out based on observations and interviews, there are several important points that need to be noted as findings: first, in the learning process using keyword methods becomes an important instrument in developing positive character values in students. Second, positive values applied to students include: honesty, responsibility, patriotism, caring, tolerance, discipline, creative, independent, and democratic to be typical of Madrasah Aliyah al-Ikhlas of Ujung in shaping the character of its students. Third, as a senior high school, the Madrasah Aliyah al-Ikhlas, based on Islamic boarding schools, promotes memorized traditions of verses or prophetic traditions relating to noble and noble moral formation to

57 Interview with Murdani, Akidah Teacher of Madrasah Aliyah Al-Ikhlas, February 22, 2018.

${ }^{58}$ Interview with Abd. Rajab, Head Master of Madrasah Aliyah Al-Ikhlas February 23, 2018.

59 Interview with Herman, English Teacher of Madrasah Aliyah Al-Ikhlas, February 21, 2018. 
all of its students. The principle is memorizing and implementing it in everyday life. Fourth, in the process of developing noble values, innovation and continuous development are needed in accordance with the level of psychology of students in each phase of education. Considering psychologically the most needed supervision in participating in fostering students.

\section{Conclusion}

The process of developing Islamic education values in the students of Madrasah Aliyah al-Ikhlas in this research article includes three stages: 1) Introduction, 2) Discussion, 3) Conclusion. The indicators of preliminary learning activities include pronunciation of greetings, delivery of apperception, delivery of the scenes, and withdrawal of attention. In the use of instructional media for teachers in Madrasah, the learning process is assisted by complete facilities such as the use of LCD, so that the method is more varied. The indicator can be seen in the use of normative methods, such as lectures that is no longer dominant. The concept of learning strategies in Madrasah is supported by the status of Madrasah with quality above the average Madrasah in Bone. Teachers, management of school organizations and students must have special standards to get in at this school. The values invested in Madrasah Aliyah al-Ikhlas, namely honesty, accountabiliy, patriotism, social care, love of peace, tolerance, discipline, and creativity, are highly recommended in Islamic teachings and are part of those who believe and fear Allah Swt.

The development of character values in Madrasah Aliyah Al-Ikhlas is carried out through integrated supervision for all school components towards the behavior of students, providing motivation, advice and stories of successful people. Application of learning strategies with active learning models to improve learning activities is a follow-up to the agreement of teachers in Madrasah. In addition, increasing the creativity and professionalism of teachers, practicing the true teachings of religion, and conducting learning evaluation activities are very important. Creative teachers will be better to manage their classes, so that student can learn optimally and achieve learning goal, which begins with a conducive and effective learning environment, so the teacher should complete and improve their competence.

\section{References}

Abdul Majid, Muhaimin, Pemikiran Pendidikan, Kajian Filosofis dan Kerangka Dasar Operasionalisasinya, Bandung: PT. Trigenda Karya, 2007.

Achmadi, Ideologi Pendidikan Islam, Yogyakarta: Pustaka Pelajar, 2010.

Ali, Muhammad, Strategi Penelitian Pendidikan, Bandung:Angkasa, 2007.

al-Qardhawi, Yusuf, Pendidikan Islam Dan Madrasah, Hasan al-Banna, Trans, Bustami A.Gani and Zainal Abidin Ahmad, Jakarta: Bulan Bintang, 1980.

Al-Taoumy al-Syaibani, Omar, Muhammad, Falsafah Pendidikan Islam, Trans. Hasan Langgulung, Jakarta: Bulan Bintang, 2003.

Aqil Siradj, Said, Tarbiyah dan Kebangsaan: Kontribusi Kaum Santri Melampaui Eksklusivisme dalam "Tasawuf Sebagai Kritik Sosial, Mengedepankan Islam sebagai Inspirasi, Bukan Aspirasi" Bandung: Mizan, 2006.

Arifin, M, Ilmu Pendidikan Islam Suatu Tinjauan Teoritis dan Praktis Berdasarkan Pendekatan Interdisipliner, Jakarta: Bumi Aksara, 1991.

Azra, Azyumardi, Esei-esei Intelektual Muslim dan Pendidikan Islam, Jakarta: Logos Wacana IImu, 1998.

Azra, Azyumardi, Pendidikan Islam Tradisi dan Modernisasi Menuju Milenium Baru, Jakarta: Logos Wacana Ilmu, 2007.

Kementerian Agama RI, al-Quran dan Terjemahnya, Semarang: PT; Thoha Putra, 2003.

Koesoma A, Doni, Pendidikan Karakter: Strategi Mendidik Anak di Zaman Global, Jakarta: Grasindo, 2007.

Langgulung, Hasan, Beberapa Pemikiran tentang Pendidikan Islam, Bandung: al-Ma'arif, 1980.

Marimba, Ahmad, Pengantar Filsafat Pendidikan Islam, Bandung: al-Ma'arif, 2000.

Marjuni, H A., "Pengembangan pendidikan Islam pada Fakultas Tarbiyah dan Keguruan UIN Alauddin Makassar dalam kerangka 
transformasi sosial", disertation UIN Alauddin Makassar, 2011.

Marzuki, Metodologi Riset, Yogyakarta: t. pn, 2008. Muhadjir, Noeng, Ilmu Pendidikan dan Perubahan Sosial: Suatu Teori Pendidikan, Yogyakarta: Rake Sarasin, 2007.

Muhaimin Azzet, Akhmad, Urgensi Pendidikan Karakter di Indonesia: Revitalisasi Pendidikan Karakter terhadap Keberhasilan Belajar dan Kemajuan Bangsa, Jakarta:Ar-Ruzz Media, 2011.

Nasution, S, Metode Research, Jakarta: Bumi Aksara, 2007.

Profile of Madrasah Aliyah Al-Ikhlas Ujung, Bone, 2018

Rosmiaty Aziz, $\mathrm{Hj}$, “Pelaksanaan Pendidikan Islam dalam Membentuk Akhlak Mulia Peserta Didik di MTs Madani Pao-Pao", dissertation UIN Alauddin Makassar, 2014.

Rukman, H, "Implementasi manajemen mutu terpadu pada MAN Baraka Kabupaten Enrekang", dissertation UIN Alauddin Makassar, 2013.
Sohra, Sarifa, "Strategi Guru Pendidikan Agama Islam dalam Mengembangkan Pendidikan Karakter Pada Peserta Didik SMA Negeri 1 Watampone", dissertation UIN Alauddin Makassar, 2014.

Sugiyono, Metode Penelitian Pendidikan Pendekatan Kualitatif, Kualitatif, dan R\&D, Bandung: Alfabeta, 2008.

Sukmadinata, Metode Penelitian Pendidikan, Bandung: Rosdakarya, 2006.

Suyanto, Urgensi Pendidikan Karakter, see website Ditjen Mandikdasmen Kementerian Pendidikan Nasional (www.kemendikbud.go.id) accessed August 8, 2017.

Usa, Muslih (ed), Pendidikan Islam di Indonesia antara Cita dan Fakta, Yogyakarta: PT Tiara Wacana Yogya, 2001.

Yuspiani, "Pengaruh Komitmen Profesi terhadap Kompetensi Profesional Guru pada Madrasah Tsanawiyah di Kota Makassar", dissertation UIN Alauddin Makassar, 2011.

Zubaedi, Desain Pendidikan karakter Konsepsi dan Aplikasinya dalam Lembaga Pendidikan Jakarta: Kencana, 2011. 